\title{
Influence of Work-Related Variables on Quality of Life of Anesthesiologists in the City of João Pessoa
}

\author{
Maria de Fátima Oliveira dos Santos ${ }^{1}$, Harison José de Oliveira ${ }^{2}$
}

\begin{abstract}
Summary: Santos MFO, Oliveira HJ - Influence of Work-Related Variables on the Quality of Life of Anesthesiologists in the City of João Pessoa.

Background and objectives: Anesthesiologists work under great pressure because they are dealing with disease, pain, suffering, and death. Exposure of these professionals to the effects of fatigue and physical, chemical, and biological factors can cause physical and psychological disorders. The objective of the present study was to understand the influences of work-related variables on anesthesiologists' quality of life in the city of João Pessoa.
\end{abstract}

Methods: This is a descriptive, transversal study with a quantitative approach, with 83 physicians who answered a generic questionnaire proposed by the World Health Organization to evaluate quality of life (QOL). Data was analyzed by descriptive statistics and mean comparison tests. The level of significance adopted for analyses was $5 \%$.

Results: Analysis demonstrated that work-related variables, i.e., the total hours of the weekly on-call schedule, working hours, sleep patterns after shifts and at shift intervals, and physical activity are all correlated with QOL. A statistically significant difference was seen between the domains of $\mathrm{QOL}$ scale and the number of working hours. On the other hand, monthly income influences $\mathrm{QOL}(\mathrm{p}<0.05)$ only in the environmental domain.

Conclusions: It was observed that work-related variables had a significant correlation with QOL. In addition to expressive statistical difference between the domains of QOL scale and the number of working hours, the same divergence was also observed regarding the environmental domain and monthly income.

Keywords: Anesthesiology; Workload; Quality of Life; Questionnaire, Occupational Health.

[Rev Bras Anestesiol 2011;61(3): 333-343] @Elsevier Editora Ltda.

\section{INTRODUCTION}

Conciliating work with quality of life (QOL) is one of the greatest problems of the modern world. The discussion about the high levels of stress caused by contemporary life is a consensus among all those who work double shifts and are always under pressure, or among those who work with imminent risks, such as the case of some medical specialties including anesthesiology whose practitioners are exposed to several factors that can change their social psycho-physiologic status since their work environment can cause stress and psychological disorders ${ }^{1,2}$.

Studies have indicated that Brazilian physicians show higher rates of signs of fatigue and suicidal ideation than the general population ${ }^{3,4}$. Among these factors, we highlight the

Received from Faculdade de Medicina Nova Esperança (FAMENE), João Pessoa, PB, Brazil.

1. Student of the Doctorate Course in Bioethics of Faculdade de Medicina da Universidade do Porto, Portugal, Anesthesiologist and Professor of Faculdade de Medicina Nova Esperança FAMENE-PB

2. Anesthesiologist of Hospital de Emergência e Trauma Senador Humberto Lucena and Hospital da Unimed João Pessoa, PB

Received on August 14, 2010

Approved on December 7, 2010

Correspondence to:

Dra. Maria de Fátima Oliveira dos Santos

Av. Umbuzeiro $881 \mathrm{Apt}^{\circ} 501$

Manaíra

58038182 - João Pessoa, PB, Brazil

E-mail: fatimadeosantos@hotmail.com excessive working-hours, increased stress due to work instability, low wages, and routine confrontation with death, pain, and suffering ${ }^{3}$.

Other degrading elements, such as sleep deprivation, which is necessary to maintain physical, mental, and psychological health also influence QOL. Studies on sleep deprivation demonstrated a progressive mental, psychological, and physical deterioration, including mood changes, decreased motor coordination and thinking capacity, memory and speech impairment, hallucinations, paranoia, and physical injuries, such as changes in heart rate and body temperature ${ }^{5}$.

Cognitive impairment causes physical and mental distress, which can leave anesthesiologists more vulnerable making them more susceptible to use/abuse of anesthetic drugs due to the pharmacological knowledge of handling and easy access $^{6}$. With the constant pressures of an increasingly demanding labor market, health professionals are faced with several challenges, such as the search for excellence and increased knowledge, but the reactive behavior has its consequences as it interferes with his/her equilibrium and QOL. Increased competitiveness, the desire to acquire more knowledge, as well as to have more resources, generate an army of busy, overworked, and pressured professionals who forget basic values and rules of well-being and living in society ${ }^{7}$.

In their jobs, anesthesiologists are in a full state of readiness and vigilance, which allow them to act quickly in critical situations, since the daily working activities they are exposed to are extremely hard ${ }^{5}$, with several stressful stimuli ${ }^{7}$. 
New health configurations and the way they affect QOL of professionals have been the topic of debates, symposiums, studies, and discussions ${ }^{3,8}$. Studies on QOL of physicians have focused specially in surgeons ${ }^{9-11}$. However, very few studies on QOL of anesthesiologists were found 7 .

Quality of life cannot be understood as just a means of investigation or closed look because it is not possible to perceive reality as it is; it demands a different look, sometimes an overlook and other times a deep look ${ }^{12,13}$. In general, authors state that it is necessary to take into consideration several dimensions of QOL. Some of them identify physical, emotional, and social aspects. Others mention physical, functional, and psychological status, as well as well-being, social interactions, and economic factors, and others focus mainly on spiritual aspects ${ }^{14-16}$.

However, most authors agree that factors involved in QOL should be considered, taken into account the 1948 definition of health by the World Health Organization (WHO) ${ }^{17}$; "Health is a state of complete physical, mental, and social well-being". Thus, individual perception is how the individual sees him/ herself, and this is what characterizes the subjective aspect of QOL ${ }^{16}$.

The WHO group of investigators developed two instruments to measure QOL: WHOQOL-100 and WHOQOL-Bref. The first consists of 100 questions that assess six domains. The second is an abbreviated version, with 26 questions from the former, covering four domains: a) physical, b) psychological, c) social relationships, and d) environment ${ }^{17-19}$.

Therefore, it is important to investigate QOL of anesthesiologists in the context of improvement proposals. The objective of the present study was to evaluate how work-related variables influence QOL of anesthesiologists in the city of João Pessoa, PB, based on objective (biodemographic) and subjective (WHOQOL-Bref) indicators. The influence of gender, diurnal or nocturnal on-call shifts, and monthly income were also investigated.

\section{METHODS}

After approval by the Research Ethics Committee of Centro de Ciências da Saúde of Universidade Federal da Paraíba (CCS/UFPB) and participants signed the informed consent, 83 associated anesthesiologists of Cooperativa dos Médicos Anestesiologistas of the city of João Pessoa, PB (COOPANEST-PB) were evaluated.

To characterize the study population, a biodemographic questionnaire with items on gender, age, and questions that allowed assessing information related to anesthesiology professionals, i.e., working hours, on-call schedule, and monthly income, among others, was elaborated. The self-applicable questionnaire was given to participants in their work place. The physician was approached and the objective of the study was explained and we requested his/her collaboration, emphasizing the importance and honesty of their answers. We explained in details how the participant could answer the questions, always making ourselves available for explaining the questionnaire, respecting and obeying ethical principles as recommended by Resolution 196/96 ${ }^{20}$ on studies with humans.

Descriptive statistical analysis (mean, standard deviation, frequency, and percentage) provided information on the study population. Afterwards, Student $t$-test for independent measurements was applied to compare the data for male and female, adopting $p<0.05$ for significant differences. Calculations were performed using the software SPSS (Statistical Package of Social Sciences for Windows) version 15.0.

\section{RESULTS}

Results were expressed as frequencies and percentages or means and standard deviation (SD) illustrated by the tables. In all questionnaires, scores were transformed to a percentage scale of $0 \%$ to $100 \%$. Scores presented here are more satisfactory as they are closer to 100 .

Participants' age ranged from 27 to 68 years $(46.0 \pm 10.41)$ (mean $\pm \mathrm{SD}$ ). This is a convenient sample (non-probabilistic) in which volunteers participated; most were male (64\%) and married (81\%), working 24 - to 36 -hour on-call shifts $(29 \%)$, non-smokers $(97.5 \%)$, with a monthly income between 21 and 30 minimum wages $(36 \%)$.

Approximately $26 \%$ of participants have parallel working activities, ranging from activities in clinics or private offices to entrepreneurs and professors. Regarding the on-call schedules, $28.9 \%$ of participants worked 24 to 36 hours per week, $26.5 \% 40$ to 60 hours, $25.3 \%$ above 60 hours weekly, and $4.8 \%$ did not take on-call duties. Almost $56 \%$ of participants work in diurnal and nocturnal on-call shifts, only $8.8 \%$ work only on night shifts, and $35.5 \%$ in diurnal shifts.

When asked about weekly hours worked outside their oncall schedule, $28 \%$ of anesthesiologists work 12 to 18 hours, $28 \% 24$ to 36 hours, and $23 \% 40$ to 60 hours. Considering the total hours worked in on-call shifts and outside them, $59 \%$ of participants worked more than 60 hours per week.

Among those who worked on-call basis, 35\% reported sleeping at the physician's quarters, $18.7 \%$ did not sleep, and $46.2 \%$ stated that sometimes they sleep during their resting time. When asked whether they can sleep after being on-call, $36.2 \%$ answered affirmatively, $13.8 \%$ did not sleep, and $50 \%$ only occasionally. Regarding daily sleeping hours, almost $63 \%$ answered they sleep between 6 and 8 hours, $34.1 \%$ less than 6 hours, and only $3.7 \%$ more than 8 hours.

Physical activities were also part of our study. Approximately $18 \%$ of participants never engage on any physical activity, $51.3 \%$ occasionally do, and $30.8 \%$ stated they always engage on physical activities. Walking or running (58.5\%) was the activity mentioned more often, followed by going to the gym (aerobics or body building) $17 \%$, and playing tennis $7.5 \% ; 97.5 \%$ of participants were non-smokers. The Portuguese abbreviated version of the WHO questionnaire, the "WHOQOL-bref", adapted by Fleck ${ }^{17}$, was used for subjective evaluation of QOL. It has 26 questions answered by a 5-point Likert-type scale, in which 2 items evaluate overall QOL and the 
Table I - Study Population Profile $(n=83)$

\begin{tabular}{|c|c|c|}
\hline Variables & Frequency & $\%$ \\
\hline \multicolumn{3}{|l|}{ Gender } \\
\hline Male & 53 & 63.9 \\
\hline Female & 30 & 36.1 \\
\hline \multicolumn{3}{|l|}{ Marital Status } \\
\hline Single & 5 & 6.0 \\
\hline Married/Stable union & 67 & 80.7 \\
\hline Divorced/Separated & 11 & 13.3 \\
\hline \multicolumn{3}{|l|}{ Monthly Income } \\
\hline Up to $20 \mathrm{x}$ minimum wage & 27 & 34.6 \\
\hline 21 to $30 \times$ minimum wage & 28 & \\
\hline Above $31 \times$ minimum wage & 23 & \\
\hline \multicolumn{3}{|l|}{ Has a parallel activity? } \\
\hline Yes & 21 & \\
\hline No & 62 & \\
\hline \multicolumn{3}{|l|}{ On-call schedule } \\
\hline Does not work on-call & 4 & \\
\hline 12 to 18 hours & 12 & \\
\hline 24 to 36 hours & 24 & \\
\hline 40 to 60 hours & 22 & 26.5 \\
\hline More than 60 hours & 21 & 25.3 \\
\hline \multicolumn{3}{|c|}{ Hours worked outside on-call schedule } \\
\hline $\begin{array}{l}\text { Doesn't work outside the on-call } \\
\text { schedule }\end{array}$ & 1 & 1.2 \\
\hline 12 to 18 hours & 23 & 28.0 \\
\hline 24 to 36 hours & 23 & 28.0 \\
\hline 40 to 60 hours & 19 & 23.2 \\
\hline More than 60 hours & 16 & 19.5 \\
\hline \multicolumn{3}{|l|}{ Total hours worked/week } \\
\hline 40 to 60 hours & 22 & 26.5 \\
\hline 12 to 18 hours & 2 & 2.5 \\
\hline 24 to 36 hours & 7 & 8.5 \\
\hline More than 60 hours & 49 & 59 \\
\hline \multicolumn{3}{|l|}{ On-call predominantly } \\
\hline Diurnal & 28 & 35.5 \\
\hline Nocturnal & 7 & 8.8 \\
\hline Diurnal and nocturnal & 44 & 55.7 \\
\hline \multicolumn{3}{|l|}{ How many hours a day do you sleep? } \\
\hline 6 to 8 hours & 51 & 62.2 \\
\hline More than 8 hours & 4 & 3.7 \\
\hline
\end{tabular}

remaining is distributed into four domains: physical, psychological, social relationships, and environment ${ }^{19}$.

In general QOL indices of physicians both general and domains-related were in the third quartile. General QOL had a mean of 59.38 with 15.17 of standard deviation; $50 \%$ of the scores were below 62.50 (median) and $50 \%$ above this value, being the same mode of this index. As can be seen in Table II, the mean was $67.44 \pm 13.88$ in physical domain; $65.79 \pm$ 13.33 in psychological domain; $63.55 \pm 13.92$ in social relations; and $62.51 \pm 11.31$ in environmental domain.

Student $t$-test was used to compare mean QOL general indices and their domains between genders. Male professionals showed higher indices than female both in general QOL and its domains, except in social domain, as shown in Table III.
Table II - Central Tendency and Dispersion of Quality of Life and its Domains

\begin{tabular}{lllll}
\hline & \multicolumn{3}{c}{ Central tendency } & \multirow{2}{*}{ Standard deviation } \\
\cline { 2 - 4 } General QOL & 59.37 & 62.50 & 62.50 & 15.17 \\
Physical & 67.44 & 71.42 & 64.29 & 13.88 \\
Psychological & 65.79 & 66.66 & 62.50 & 13.33 \\
Social & 63.55 & 66.66 & 66.67 & 13.92 \\
Environment & 62.51 & 62.50 & 68.75 & 11.31 \\
\hline
\end{tabular}

Table III - Mean Scores of Quality of Life and its Domains as a Function of Gender

\begin{tabular}{llll}
\hline & Male & Female $^{*}$ & \\
\hline General QOL & $59.50(14.39)$ & $59.17(16.72)$ & $0.95 ; p>0.05$ \\
Physical & $69.02(12.70)$ & $64.64(15.59)$ & $1.39 ; p>0.05$ \\
Psychological & $67.87(12.73)$ & $62.14(13.80)$ & $1.87 ; p>0.05$ \\
Social & $62.66(13.52)$ & $65.14(14.70)$ & $-0.78 ; p>0.05$ \\
Environment & $63.46(10.49)$ & $60.83(12.65)$ & $1.02 ; p>0.05$ \\
\hline
\end{tabular}

${ }^{*}$ Results expressed as mean (standard deviation).

However, the differences observed were not statistically significant $(p>0.05)$, i.e., although male had higher indices than female, the difference between them was not enough to be statistically valid.

To determine the influence of working hours in QOL, the indices of 34 participants who work less than 60 hours were compared to those who work more than 60 hours per week. General QOL indices, as well as the physical, psychological, and social domains showed no significant variation between both groups, as can be seen in Table IV.

Only the environmental domain showed a statistically significant difference, indicating that anesthesiologists who work less hours (66.88 \pm 12.33 ) have significantly higher indices $(p<0.005)$ than those who work more hours $(59.47 \pm 9.55)$.

The on-call shift influence on QOL of anesthesiologists was also investigated. The Student's $t$-test was used to compare QOL indices of professionals whose on-call shifts are predominantly diurnal or nocturnal with those who work diurnal and nocturnal shifts.

As shown in Table $V$, the on-call shift does not influence significantly their QOL indices, since a statistically significant difference was not observed between both groups.

To determine whether monthly income influences QOL and their components, we compared the indices of those whose monthly income is less than 20 times the minimum wage

Table IV - Mean Scores of Quality of Life and its Domains as a Function of Working Hours

\begin{tabular}{llll}
\hline & $\begin{array}{l}\text { Less than 60 } \\
\text { hours }^{*}\end{array}$ & $\begin{array}{l}\text { More than 60 } \\
\text { hours }^{*}\end{array}$ \\
\hline General QOL & $62.44(14.37)$ & $57.25(15.49)$ & $1.55 ; p>0.05$ \\
Physical & $69.67(13.63)$ & $65.89(13.98)$ & $1.23 ; p>0.05$ \\
Psychological & $66.62(13.17)$ & $65.22(13.54)$ & $0.47 ; p>0.05$ \\
Social & $66.54(13.93)$ & $61.47(13.67)$ & $1.65 ; p>0.05$ \\
Environment & $66.88(12.33)$ & $59.47(9.55)$ & $3.08 ; p<0.005$ \\
\hline
\end{tabular}

${ }^{*}$ Results expressed as mean (standard deviation). 
Table V - Mean Scores of Quality of Life and its Domains as a Function of the On-call Shift

\begin{tabular}{llll}
\hline & $\begin{array}{l}\text { Only diurnal or } \\
\text { nocturnal }\end{array}$ & $\begin{array}{l}\text { Diurnal and } \\
\text { nocturnal }\end{array}$ & t test \\
\hline General QOL & $59.79(16.56)$ & $58.48(14.40)$ & $58.48(14.40)$ \\
Physical & $67.07(12.98)$ & $66.39(14.54)$ & $66.39(14.54)$ \\
Psychological & $66.15(12.33)$ & $64.77(14.39)$ & $64.77(14.39)$ \\
Social & $63.69(15.24)$ & $63.16(13.48)$ & $63.16(13.48)$ \\
environment & $64.26(10.80)$ & $59.70(10.75)$ & $59.70(10.75)$ \\
\hline
\end{tabular}

*Results expressed as mean (standard deviation).

Table VI - Mean Scores of Quality of Life and its Domains as a Function of Monthly Income

\begin{tabular}{|c|c|c|c|c|}
\hline & Group 1* & Group 2 * & Group3 * & \\
\hline General QOL & $\begin{array}{l}58.99 \\
(17.88)\end{array}$ & $\begin{array}{l}56.25 \\
(14.63)\end{array}$ & $\begin{array}{l}62.73 \\
(12.87)\end{array}$ & $\begin{array}{l}F(2.75)= \\
1.122 ; \\
p>0.05\end{array}$ \\
\hline Physical & $\begin{array}{l}62.70 \\
(16.35)\end{array}$ & $\begin{array}{l}68.75 \\
(12.32)\end{array}$ & $\begin{array}{l}70.34 \\
(12.63)\end{array}$ & $\begin{array}{l}F(2.75)= \\
2.167 ; \\
p>0.05\end{array}$ \\
\hline Psychological & $\begin{array}{l}63.17 \\
(15.34)\end{array}$ & $\begin{array}{l}66.67 \\
(12.58)\end{array}$ & $\begin{array}{l}66.85 \\
(13.08)\end{array}$ & $\begin{array}{l}F(2.75)= \\
0.597 ; \\
p>0.05\end{array}$ \\
\hline Social & $\begin{array}{l}65.12 \\
(10.54)\end{array}$ & $\begin{array}{l}60.31 \\
(16.70)\end{array}$ & $\begin{array}{l}65.22 \\
(14.58)\end{array}$ & $\begin{array}{l}F(2.75)= \\
0.664 ; \\
p>0.05\end{array}$ \\
\hline Environment & $\begin{array}{l}57.87 \\
(12.51)\end{array}$ & $\begin{array}{l}65.46 \\
(9.34)\end{array}$ & $\begin{array}{l}64.40 \\
(11.10)\end{array}$ & $\begin{array}{l}F(2.75)= \\
3.728 ; \\
p<0.05\end{array}$ \\
\hline
\end{tabular}

${ }^{*}$ Results expressed as mean (standard deviation).

(Group 1), those whose monthly income is between 21 and 30 times the minimum wage (Group 2), and those whose monthly wage is above 31 times the minimum wage (Group 3). Analysis of Variance was used to compare the three groups and the results are shown in Table VI.

The results indicate that monthly income does not affect general QOL or the physical, psychological, and social domains. However, a difference $(p<0.05)$ was seen in the social domain; the indices of Group $2(65.46 \pm 9.34)$ were higher than those in Group $3(64.40 \pm 11.10)$, and in turn the latter were higher than those in Group 1 (57.87 \pm 12.51$)$. To determine whether this difference persisted in all levels of this variable, a multiple comparison using Scheffe's test was performed. Through this analysis, we verified that the difference was statistically significant only when comparing Groups 2 and 1, i.e., only anesthesiologists whose monthly income was between 21 and 30 times the minimum wage had medium indices in the environmental domain that were statistically higher than those whose monthly wage is lower than 20 times the minimum wage.

\section{DISCUSSION}

Work-related variables, such as exhausting on-call schedules, unhealthy environment, and loss of professional autonomy are responsible for causing physical and mental impairment, problems and psychological and physiological dysfunctions in health care professionals, which can hinder their working dynamics ${ }^{4,21}$ and QOL. For this reason, the objective of the present study was to assess how working activities affect QOL of anesthesiologists in the city of João Pessoa (PB). Despite some limitations inherent to this study, especially concerning the study sample, which, besides being of convenience (nonprobabilistic) is not representative of the population being investigated, which does not invalidate the study, we believe that our goal was reached.

Results demonstrated that QOL showed a negative correlation with total hours of weekly on-call and working hours, indicating that the greater the number of working hours the lower the QOL of health care professional ${ }^{3}$. In addition, it was observed that QOL also decreases with the decrease in hours a professional can sleep after being on-call or during intervals in their on-call schedule, an indication that work stress and physical and mental fatigue are obstacles to sleep. The variable "physical activity" showed a positive correlation with QOL, indicating that better QOL indices are associated with the number of hours professionals dedicate to physical activities.

Regarding total QOL scores and physical, psychological, social, and environmental factors, a statistically significant difference between male and female was not observed. We also observed a statistically significant difference between "working hours" and general QOL, as well as its domains, indicating that, the greater the number of working hours, more the professional feels injured, both in general and in the physical, social, psychological, and environmental domains. Thus, the perception the individual has of oneself and his/her position in life (context, culture, value system, expectations, objectives, and concerns) ${ }^{13,18}$ is hindered. Those with greater working load have less time to rest, enjoy leisure time, and socialize with family and friends 28 .

Regarding the influence of monthly income, it was observed that only the environmental factor showed a statistically significant difference. Group 2 (21 to 30 times the minimum age) showed higher indices than Group $1(\leq 20$ times the minimum wage) and Group 3 (above 31 times the minimum wage). Although Group 3 had a higher income, which enable them to use more often some aspects of the domain environment, such as leisure activities, safety, and health, they do not have enough free time for those activities.

This study indicates the need for additional studies to add information about the matter focused here. Quality of life of anesthesiologists consists of a complex system that is difficult to measure, since it involves factors that are external and internal to the individual, such as subjectivity and social-cultural context. More studies are required to further investigate factors that influence anesthesiologists QOL aiming at improvement changes. We suggest future analysis of aspects affecting the professionals' health, such as: Positive and Negative Affect Scale ${ }^{22}$, Subjective Vitality Scale ${ }^{23}$, General Health Questionnaire (GHQ-12) ${ }^{24}$, Fatigue Assessment Scale ${ }^{25}$, Maslach Burnout Inventory ${ }^{26}$, and Satisfaction with Life Scale ${ }^{27}$. 


\section{CONCLUSION}

The results of the present study indicate that work-related variables are significantly correlated with QOL since, besides showing an expressive statistical difference between the domains of QOL scale and the number of working hours, the same was observed regarding the domains environment and monthly income. The lack of leisure activities and time spent with their families, along with long working hours may trigger physical and psychological problems and also hinder performance of these health professionals, indicating the need for change of attitude and awareness regarding excessively long working activities.
We also believe investigators should pay more attention to different ways of understanding QOL, especially valorizing study methods and interdisciplinary assessment.

\section{ACKNOWLEDGEMENTS}

Our acknowledgements to the anesthesiologists of Coopanest PB and Sociedade Paraibana de Anestesiologia da Cidade de João Pessoa. 


\section{REFERÊNCIAS / REFERENCES}

01. Karasek RA, Theorell T - Healthy Work: Stress, Productivity and the Reconstruction of Working Life. New York, Basic Books, 1990;89103.

02. Glina DMR, Rocha LE, Batista $M L$ et al. - Saúde mental e trabalho: uma reflexão sobre o nexo com o trabalho e o diagnóstico, com base na prática. Cad Saúde Pública, 2001;17:607-616.

03. Oliveira GF, Barbosa GA, Souza LEC et al. - Satisfação com a vida entre profissionais da saúde: correlatos demográficos e laborais. Rev Bioética, 2009;17:319-334.

04. Barbosa GA, Andrade EO, Carneiro MB et al. - A Saúde dos Médicos no Brasil. Brasília, Conselho Federal de Medicina, 2007.

05. Mathias LAST, Coelho CMF, Vilela EP et al. - O plantão noturno em anestesia reduz a latência ao sono. Rev Bras Anestesiol, 2004;54:693699.

06. Niel M, Julião AM, Martin D et al. - Uso de drogas entre anestesiologistas no contexto das relações de trabalho. RBPS, 2008;21:194200.

07. Calumbi RA, Amorim JA, Maciel CMC et al. - Avaliação da qualidade de vida dos anestesiologistas da cidade do Recife. Rev Bras Anestesiol, 2010;60:42-51.

08. Gouveia RSV, Lins ZMB, Lima TJS et al. - Bem-estar afetivo entre profissionais de saúde. Rev Bioética, 2009;17:267-280.

09. Schmidt DRC, Dantas RAS - Qualidade de vida no trabalho de profissionais de enfermagem, atuantes em unidades do bloco cirúrgico, sob a ótica da satisfação. Rev Latinoam Enferm, 2006;14:54-60.

10. Franco GP, Barros ALBL, Nogueira-Martins LA - Qualidade de vida e sintomas depressivos em residentes de enfermagem. Rev Latinoam Enferm, 2005;13:139-144.

11. Rocha SSL, Felli VEA - Qualidade de vida no trabalho docente em enfermagem. Rev Latinoam Enferm, 2004;12:28-35.

12. Dantas RAS, Sawada NO, Malerbo MB - Pesquisas sobre qualidade de vida: revisão da produção científica das universidades públicas do Estado de São Paulo. Rev Latinoam Enferm, 2003;1 1:532-538.

13. Moreno $A B$, Faerstein $E$, Werneck $G L$ et al. - Propriedades psicométricas do instrumento abreviado de avaliação de qualidade de vida da Organização Mundial da Saúde no estudo pró-saúde. Cad Saúde Pública, 2006;22:2585-2597.

14. Renwick R - Quality of Life: a Guiding Framework for Practice with Adults with Developmental Disabilities, em: Ross M, Bachner $S$ - Adults with Developmental Disabilities. New York, Aota Press, 2004;20-38.

15. Fleck MPA, Borges ZN, Bolognesi $G$ et al. - Desenvolvimento do WHOQOL, módulo espiritualidade, religiosidade e crenças pessoais. Rev Saúde Pública, 2003;37:446-455.

16. Skevington SM, Lotfy M, O'Connell KA et al. - The World Health Organisations WHOQOL-Bref quality of life assessment: psychometric properties and the results of the international field trial. A report from the WHOQOL group. Qual Life Res, 2004;13:299-310. 
17. Fleck MPA, Louzada $S$, Xavier $M$ et al. - Aplicação da versão em português do instrumento abreviado de avaliação da qualidade de vida "WHOQOL-bref". Rev Saúde Pública, 2000;34:178-183.

18. The WHOQOL Group - The World Health Organization Quality of Life assessment (WHOQOL): position paper from the World Health Organization. Soc Sci Med, 1995;41:1403-1409.

19. Fleck MPA, Leal OF, Louzada S et al. - Desenvolvimento da versão em português do instrumento de avaliação de qualidade de vida da OMS (WHOQOL-100). Rev Bras Psiquiatr, 1999;21:19-28.

20. Brasil. Ministério da Saúde. Conselho Nacional de Saúde - Resolução n 196/96 sobre Pesquisa Envolvendo Seres Humanos, 1996. Disponível em: <http://www.saude.gov.br>

21. Pimentel D - O sonho do jaleco branco: Saúde Mental dos Profissionais de Saúde, Aracaju, Editora da UFS, 2005.

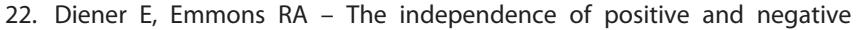
affect. J Pers Soc Psychol, 1984;47:1105-1117.

23. Ryan RM, Frederick CM - On energy, personality and health: Subjective vitality as a dynamic reflection of well-being. J Pers, 1997;65:259-565.

24. Pasquali L, Gouveia VV, Andriola WB et al. - Questionário de saúde geral de Goldberg (QSG): adaptação brasileira. Psicol Teor Pesq, 1994;10:421-437.

25. Michielsen HJ, De Vries J, Van Heck GL et al. - Examination of the dimensionality of fatigue. The construction of the Fatigue Assessment Scale (FAS). Eur J Psychol Assess, 2004;20:39-48.

26. Maslach C, Jackson SE - Maslach Burnout Inventory Manual, $2^{\text {nd }}$ Ed, Palo Alto, CA, Consulting Psychologist Press, 1986.

27. Diener E, Emmons RA, Larsen RJ et al. - The satisfaction with life scale. J Pers Assess, 1985;49:71-75.

28. Silva JVP, Nunez PRM - Qualidade de vida, perfil demográfico e profissional de professores de educação física. Pensar a Prática, 2009;12:1-11.

Resumen: Santos MFO, Oliveira HJ - Influencia de las Variables Laborales en la Calidad de Vida de los Anestesiólogos de la Ciudad de João Pessoa.
Justificativa y objetivos: El anestesiólogo trabaja bajo una fuerte presión por tener que lidiar con la enfermedad, el dolor, el sufrimiento y la muerte. Su exposición a los efectos del cansancio, factores físicos, químicos y biológicos puede causar trastornos físicos y psicológicos. Este estudio intentó conocer las influencias de las variables laborales en la CV de los anestesiólogos de la ciudad de João Pessoa.

Método: Estudio descriptivo, de corte transversal y con un abordaje cuantitativo, compuesto por 83 médicos que respondieron al instrumento genérico para evaluar la calidad de vida (CV), propuesto por la Organización Mundial de la Salud. Los datos fueron analizados por estadísticas descriptivas y por el test de comparación de promedio. El nivel de significancia adoptado para los análisis fue de un de $5 \%$.

Resultados: Los análisis demostraron que las variables laborales relacionadas con el total de horas de guardias semanales con las horas trabajadas, con el hábito de dormir después de la guardia y en los intervalos de las mismas, junto con la práctica de la actividad física por parte del profesional, se correlacionaron con la CV. Verificamos también, que hay una diferencia estadísticamente significativa entre los dominios de la escala de CV y el número de horas de trabajo de los participantes. Por otra parte, el salario mensual ejerce una influencia sobre la CV $(p<0,05)$ solo en el dominio del medio ambiente.

Conclusiones: Observamos que las variables laborales se correlacionaron significativamente con la CV. Además de haber una diferencia estadística expresiva entre los dominios de la escala de CV y el número de horas de trabajo de los participantes, se verificó que también existe esa misma divergencia en cuanto al dominio del medio ambiente y al salario mensual.

Descriptores: ANESTESIOLOGÍA: Calidad; TÉCNICAS DE MEDCIÓN: Cuestionario. 